\title{
INTESTINAL HELMINTHS INFECTION OF RATS (RATUS NORVEGICUS) IN the Belgrade aRea (Serbia): the efFect OF SEX, AGE AND habitat ${ }^{1}$
}

\author{
KATARANOVSKI M.*, MIRKOV I.*, BELIJ S.*, POPOV A.*, PETROVIĆ Z.**, GAČIĆ Z.*** \& KATARANOVSKI D.*
}

\section{Summary:}

Gastrointestinal helminths of Norway rat (Rattus norvegicus) from the Belgrade area were studied as a part of a wider ecological research of rats in Serbia (data on the distribution, population ecology, economic and epizoothiological-epidemiological importance, and density control). Rats were captured from May 2005 to July 2009 at both urban and suburban-rural sites. Of a total of 302 trapped rats $48 \%$ were males and $52 \%$ females, with $36.5 \%$ and $38.8 \%$ of juvenile-subadult individuals, per sex respectively. Intestinal helminth infection was noted in $68.5 \%$ of rats, with a higher prevalence in male hosts and in adult individuals. Higher numbers of infected juveniles-subadults were noted in suburban-rural habitats, while an opposite tendency was noted in adult rats. Seven helminth species were recovered, of which five were nematode (Heterakis spumosa, Nippostrongylus brasiliensis, Capillaria sp., Trichuris muris and Syphacia muris) and two cestode species (Hymenolepis diminuta and Rodentolepis fraterna). The most prevalent parasites were Heterakis spumosa (36.7 \%) and Hymenolepis diminuta (30.5\%). Sex and habitat-related differences were noted in the prevalence of infection with Capillaria sp. and Trichuris muris, while there were no age-related differences in the prevalence of infection with any individual helminth species. Significantly higher prevalence of infection was noted in summer as compared to spring or winter with a tendency to be higher in autumn as compared to spring. The only significant difference in the prevalence of infection between habitat-related was noted during spring. H. spumosa was most prevalent in summer, while $H$. diminuta and $N$. brasiliensis in autumn. The mean intensity of infection with $\mathrm{H}$. spumosa, $R$. fraterna, S. muris and T. muris was higher in autumn than in the other seasons, while N. brasiliensis and Capillaria sp. occured in winter. No more than four helminth species were found in one host.

KEY WORDS: Rattus norvegicus, intestinal helminths, nematodes, cestodes, Serbia.

$\mathrm{N}$ orway rat, Rattus norvegicus (Berk, 1769), is a cosmopolitan rodent species with a wide distribution in urban and suburban-rural habitats, commonly found living near sources of food and water, such as refuse and drainage ditches, streams or sewers (Kataranovski, 1999). Because of its high ability

\footnotetext{
* Department of Ecology, Institute for Biological Research "Siniša Stanković", University of Belgrade, Belgrade, Serbia.

*** Institute of Meat Hygiene and Technology, Belgrade, Serbia.

**** Institute for Multidisciplinary Research, Belgrade, Serbia. Correspondence: Dragan Kataranovski.

Tel.: 381112078397 - Fax: 381112761433

E-mail: dragan@ibiss.bg.ac.rs

${ }^{1}$ This article is based on an oral presentation given at the international conference "Parasitic zoonoses in present day Europe", Belgrade, 18-20 November 2009.
}

Résumé : HELMINTHOSES INTESTINALES DU RAT (RATUS NORVEGICUS) dANS LA RÉGION de BeLgRAde (SERBie) EN FONCTION DU SEXE, DE L'ÂGE ET DE L'HABITAT

Les helminthes digestives de Rattus norvegicus de la région de Belgrade ont été étudiées dans le cadre d'une vaste recherche menée sur les rats en Serbie (répartition et écologie des populations, conséquences économiques et épizoo-épidémiologiques, contrôle des densités de populations). Les rats ont été capturés entre mai 2005 et juillet 2009 en zones urbaines et périurbaines et rurales. Sur un total de 302 captures, on comptait $48 \%$ de mâles et $52 \%$ de femelles, avec respectivement $36,5 \%$ et 38,8 \% d'individus juvéniles ou préadultes. Au moins une helminthose intestinale a été retrouvée chez $68,5 \%$ des rats, avec une fréquence plus élevée chez les mâles et les adultes. Un nombre plus important de juvéniles et de préadultes infectés a été observé en zones suburbaines et rurales, avec une tendance inverse chez les adultes. Sept espèces d'helminthes ont été retrouvées, dont cinq nématodes (Heterakis spumosa, Nippostrongylus brasiliensis, Capillaria sp., Trichuris muris et Syphacia muris) et deux cestodes (Hymenolepis diminuta et Rodentolepis fraterna), les plus fréquents étant Heterakis spumosa (36,7\%) et Hymenolepis diminuta $(30,5 \%)$. Des variations liées au sexe et à l'habitat ont été notées pour Capillaria sp. et Trichuris muris, mais sans différence liée à l'âge pour chacune des helminthoses. La fréquence des infections était plus importante en été qu'au printemps et en hiver, avec une tendance à être plus élevée en automne qu'au printemps. La seule différence significative selon l'habitat a été observée au printemps. H. spumosa a été plus fréquemment retrouvé en été, $\mathrm{H}$. diminuta et $\mathrm{N}$. brasiliensis en automne. L'intensité moyenne des infections était plus importante en automne pour $\mathrm{H}$. spumosa, R. fraterna, S. muris et T. muris, et en hiver pour $\mathrm{N}$. brasiliensis et Capillaria sp. Un maximum de quatre helminthes a été observé chez un même individu.

MOTS-CLÉS : Rattus norvegicus, helminthose intestinale, nématode, cestode, Serbie.

to harbor many zoonotic agents, wild Norway rats play a significant role as definitive and/or intermediate hosts for vector-borne animal and human diseases (Bradshaw, 1999; Battersby et al., 2002; Easterbrook et al., 2007). The diversity of distribution of Norway rats in urban, suburban and particularly rural areas, and consumption of a variety of foods as well as materials of human and animal origin, attribute to their exposure to diverse parasitic infections.

While reports of gastrointestinal helminthic parasites of populations of $R$. norvegicus from temperate regions of Europe are numerous (Feliu et al., 1985, 1997; Webster \& Macdonald, 1995; Webster, 1997; Ceruti et al., 2001; Stojčević et al., 2004; Redrobe \& Patterson-Kane, 2005), there is a lack of data concerning intestinal helminth 
fauna in $R$. norvegicus in Serbia. Wild $R$. norvegicus is the dominant rat species in this area (Kataranovski, 1999), and represents an important pest rodent. Recently, data on Calodium hepaticum (= Capillaria hepatica) and Taenia (= Hydatigera) taeniaeformis larvae (Cysticercus fasciolaris) liver infections in $R$. norvegicus were reported (Kataranovski et al., 2010), which represent the first record of these parasites in wild Norway rats in Serbia.

The aim of this study was to examine intestinal helminth fauna of Norway rats from Belgrade area and to investigate the impact of internal (host) factors such as sex and age as well as external factors including different environments (urban or suburban-rural) and season on the prevalence of helminth infection.

\section{MATERIALS AND METHODS}

A total of 302 rats were captured during four consecutive years, from May 2005 to July 2009. The sample includes all the seasons in the studied years. Rats were collected from different sites (urban and suburban-rural) of the Belgrade area $\left(44^{\circ} \mathrm{N}, 20^{\circ} \mathrm{E}\right.$, approximate geometric center of Belgrade 44049'14" N, $20^{\circ} 27^{\prime} 44^{\prime \prime}$ E). Urban sites of Belgrade area were characterized by high population density. Suburban-rural sites of the Belgrade area are with lower population density situated at the outskirts of urban site or small isolated areas of open country with sporadic houses and crofts (barns, stables, pigsties, chicken coops, pens). Animals were captured using snap live traps $(14 \times 16.5 \times 32 \mathrm{~cm})$. Live traps were baited with pieces of smoked bacon and/or fresh-water fish, and were active for five consecutive days per three urban and three suburban-rural stations and season. The captured rats were transported to the animal facility of the Institute for Biological Research "Siniša Stanković", Belgrade and examined 24-48 hours after trapping. Animal procedures were carried out in adherence to the Ethical Committee of the Institute for Biological Research "Siniša Stanković", Belgrade. The animals were fed commercial rodent feed and had access to water ad libitum. After 24-48 hours the rats were euthanized by barbiturate anesthesia overdose.

For each rat examined, the data on trapping locality, body length (head and body), weight and sex were noted. Rats were classified into juveniles-subadults $(<2.5$ months old) and adults ( $>2.5$ months old) according to body weight (borderline value $200 \mathrm{~g}$ ) and the weight of the dry eye lens pairs $(14.3 \mathrm{mg}$ ) as shown previously (Kataranovski et al., 1994).

The material was analyzed using standard parasitological procedures. The stomach, small intestine, cecum and colon were separated from the surrounding fat tissue and placed into individual Petri dishes containing saline. They were opened longitudinally and examined for helminth parasites. Parasites were carefully removed, identified and counted under a stereoscopic microscope (Kruss and Olympus BO61 binoculars and Olympus $\mathrm{CHC}$ and Carl Zeiss). The identification of helminths of Norway rat was based on Key To Helminths of Rodents of the Fauna of the USSR (1978, 1979) and descriptions given by Genov (1984). The parasitological terminology and quantitative parameters were according to Buch et al. (1997). Quantitative descriptors of parasite infection were calculated, including prevalence or percent infected, percent infestation, extent of infection, extensity $(\mathrm{P}=$ $\mathrm{n} / \mathrm{Z} \times 100)$, mean intensity of infection $(\mathrm{MI}=\mathrm{N} / \mathrm{n})$ and mean abundance of infection $(\mathrm{MA}=\mathrm{N} / \mathrm{Z})$ where: $\mathrm{n}=$ number of animals (hosts) infected, $\mathrm{N}=$ total number of parasites, and $Z=$ total number of animals infected and non-infected. Also, according to Kisielewska (1970), the infection index or invasion index $\left(\mathrm{I}=\mathrm{N} \times \mathrm{n} / \mathrm{Z}^{2}\right)$ was calculated. Statistical analysis was performed using difference between two proportions and Mann-Whitney U-test (STATISTICA 6.0, StatSoft Inc., Tulsa, Oklahoma, USA).

The studied material has been stored in the collection of the Helminthologic section, Department of Ecology, Institute for Biological Research, "Siniša Stanković", Belgrade, Serbia.

\begin{tabular}{|c|c|c|c|}
\hline & Males & Females & $\mathbf{p}$ \\
\hline $\begin{array}{l}\text { Number of rats } \\
\text { Infected }\end{array}$ & $\begin{array}{l}145 \\
76.5^{*}\end{array}$ & $\begin{array}{c}157 \\
61.1\end{array}$ & \\
\hline Infected & $\begin{array}{l}56.6 \\
81.7^{*}\end{array}$ & $\begin{array}{l}47.8 \\
68.0\end{array}$ & 0.0490 \\
\hline $\begin{array}{l}\text { Suburban-rural } \\
\qquad \text { Infected }\end{array}$ & $\begin{array}{l}43.4 \\
69.8^{*}\end{array}$ & $\begin{array}{l}52.2 \\
54.9\end{array}$ & 0.0339 \\
\hline $\begin{array}{r}\text { Juvenile-subadult rats } \\
\text { Infected }\end{array}$ & $\begin{array}{l}36.5 \\
67.9\end{array}$ & $\begin{array}{l}38.2 \\
55.0\end{array}$ & 0.0800 \\
\hline Infected & $\begin{array}{l}46.9 \\
81.6 *\end{array}$ & $\begin{array}{l}51.7 \\
61.3\end{array}$ & 0.0324 \\
\hline $\begin{array}{l}\text { Suburban-rural } \\
\quad \text { Infected }\end{array}$ & $\begin{array}{l}23.8 \\
33.3\end{array}$ & $\begin{array}{l}48.3 \\
48.3\end{array}$ & 0.1732 \\
\hline Adult rats & $\begin{array}{l}63.4 \\
81.5^{* \#}\end{array}$ & $\begin{array}{l}61.8 \\
64.9\end{array}$ & $0.0055,0.0324$ \\
\hline Infected & $\begin{array}{l}47.8 \\
78.3\end{array}$ & $\begin{array}{l}45.4 \\
72.7 \#\end{array}$ & $0.2750,0.0342$ \\
\hline $\begin{array}{l}\text { Suburban-rural } \\
\text { Infected }\end{array}$ & $\begin{array}{l}90.6 \\
81.2^{*}\end{array}$ & $\begin{array}{l}88.3 \\
58.5\end{array}$ & 0.0076 \\
\hline
\end{tabular}

Significantly different from females at $* \mathrm{p}<0.05$, from juvenilesubadults at ${ }^{*} \mathrm{p}<0.05$ ( $3^{\text {rd }}$ column)

Table I. - Prevalence of intestinal helminth infection in rats of different sex, age and from different habitats. 


\section{RESULTS}

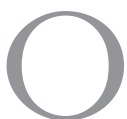

$\mathrm{f}$ all Norway rats, $48.0 \%$ were males and $52 \%$ were females. All rats were separated in two age groups, juvenile-subadult $(37.4 \%)$ and adult $(62.6 \%)$. Intestinal helminths were found in 207 rats $(68.5 \%)$. A higher prevalence of infection was noted in male compared to female rats, owing to infection in animals of this sex from both localities (Table I). Higher prevalence of infection in males is mainly due to juvenile-subadults and adults in urban and suburban-rural habitats, respectively.

Helminthological analysis showed the presence of seven species of parasites, as follows: five Nematoda

\begin{tabular}{|c|c|c|c|c|c|c|c|c|c|}
\hline \multicolumn{3}{|c|}{ Helminth species } & $\mathbf{n}$ & $\mathbf{N}$ & $\mathbf{Z}$ & $\mathbf{P} \%$ & I & MI & MA \\
\hline \multirow[t]{6}{*}{ (Part 1) } & Heterakis spumosa & male & 54 & 437 & 145 & 37.2 & 1.1224 & 8.1 & 3.0 \\
\hline & & female & 57 & 460 & 157 & 36.3 & 1.0637 & 8.1 & 2.9 \\
\hline & Hymenolepis diminuta & male & 50 & 319 & 145 & 34.5 & 0.7586 & 6.4 & 2.1 \\
\hline & & female & 42 & 261 & 157 & 26.7 & 0.4447 & 6.2 & 1.7 \\
\hline & Rodentolepis fraterna & male & 22 & 132 & 145 & 15.2 & 0.1381 & 9.0 & 0.9 \\
\hline & & female & 16 & 87 & 157 & 10.2 & 0.0565 & 5.4 & 0.5 \\
\hline \multirow{8}{*}{$\begin{array}{c}\text { Combined } \\
\text { habitats }\end{array}$} & Nippostrongylus brasiliensis & male & 27 & 370 & 145 & 18.6 & 0.4751 & 13.7 & 2.5 \\
\hline & & female & 22 & 307 & 157 & 14.0 & 0.3212 & 13.9 & 2.0 \\
\hline & Capillaria sp. & male & 14 & 126 & 145 & $9.7^{*}$ & 0.0839 & 9.0 & 0.9 \\
\hline & & female & 4 & 55 & 157 & 2.5 & 0.0089 & 13.7 & 0.3 \\
\hline & Trichuris muris & male & 11 & 49 & 145 & 7.6 & 0.0256 & 4.4 & 0.3 \\
\hline & & female & 7 & 37 & 157 & 4.5 & 0.0105 & 8.3 & 0.2 \\
\hline & Syphacia muris & male & 6 & 50 & 145 & 4.1 & 0.0142 & 8.3 & 0.3 \\
\hline & & female & 7 & 47 & 157 & 4.5 & 0.0133 & 6.7 & 0.3 \\
\hline \multirow{6}{*}{ (Part 2) } & Heterakis spumosa & male & 29 & 242 & 81 & 35.8 & 1.0696 & 8.3 & 3.0 \\
\hline & & female & 26 & 220 & 76 & 34.2 & 0.9903 & 8.5 & 2.8 \\
\hline & Hymenolepis diminuta & male & 34 & 187 & 81 & 42.0 & 0.9691 & 5.5 & 2.3 \\
\hline & & female & 23 & 117 & 76 & 30.3 & 0.4659 & 5.1 & 1.5 \\
\hline & Rodentolepis fraterna & male & 16 & 73 & 81 & 19.7 & 0.1780 & 4.6 & 0.9 \\
\hline & & female & 12 & 69 & 76 & 15.8 & 0.1434 & 5.7 & 0.9 \\
\hline \multirow{8}{*}{$\begin{array}{l}\text { Urban } \\
\text { habitat }\end{array}$} & Nippostrongylus brasiliensis & male & 13 & 146 & 81 & 16.0 & 0.2893 & 11.2 & 1.8 \\
\hline & & female & 10 & 127 & 76 & 13.2 & 0.2199 & 12.7 & 1.7 \\
\hline & Capillaria sp. & male & 12 & 127 & 81 & $14.8^{* \#}$ & 0.2323 & 10.6 & 1.6 \\
\hline & & female & 3 & 27 & 76 & 3.9 & 0.0140 & 9.0 & 0.4 \\
\hline & Trichuris muris & male & 7 & 36 & 81 & 8.6 & 0.0384 & 5.1 & 0.4 \\
\hline & & female & 6 & 28 & 76 & $7.9 \#$ & 0.0291 & 4.7 & 0.4 \\
\hline & Syphacia muris & male & 6 & 53 & 81 & 7.4 & 0.0485 & 8.8 & 0.6 \\
\hline & & female & 5 & 38 & 76 & 6.6 & 0.0328 & 7.6 & 0.5 \\
\hline \multirow{14}{*}{$\begin{array}{c}\text { Suburban-rural } \\
\text { habitat }\end{array}$} & Heterakis spumosa & male & 25 & 217 & 64 & 39.1 & 1.3245 & 8.7 & 3.4 \\
\hline & & female & 31 & 218 & 81 & 38.3 & 1.0300 & 7.0 & 2.7 \\
\hline & Hymenolepis diminuta & male & 16 & 129 & 64 & 25.0 & 0.5039 & 8.1 & 2.0 \\
\hline & & female & 19 & 147 & 81 & 23.5 & 0.4257 & 7.7 & 1.8 \\
\hline & Rodentolepis fraterna & male & 6 & 44 & 64 & 9.4 & 0.0645 & 7.3 & 0.7 \\
\hline & & female & 4 & 33 & 81 & 4.9 & 0.0201 & 8.2 & 0.4 \\
\hline & Nippostrongylus brasiliensis & male & 14 & 209 & 64 & 21.9 & 0.7144 & 14.9 & 3.3 \\
\hline & & female & 12 & 195 & 81 & 14.8 & 0.3567 & 16.2 & 2.4 \\
\hline & Capillaria sp. & male & 2 & 18 & 64 & 3.1 & 0.0088 & 9.0 & 0.3 \\
\hline & & female & 1 & 7 & 81 & 1.2 & 0.0011 & 7.0 & 0.1 \\
\hline & Trichuris muris & male & 4 & 18 & 64 & 6.2 & 0.0176 & 4.5 & 0.3 \\
\hline & & female & 1 & 4 & 81 & 1.2 & 0.0006 & 4.0 & 0.1 \\
\hline & Syphacia muris & male & 0 & 0 & 64 & 0.0 & 0.0000 & 0.0 & 0.0 \\
\hline & & female & 2 & 6 & 81 & 2.5 & 0.0018 & 3.0 & 0.1 \\
\hline
\end{tabular}

Part 1: significantly different from females at $* \mathrm{p}<0.05$; Part 2: significantly different from females at $* \mathrm{p}<0.05$; from urban habitats at ${ }^{*} \mathrm{p}<0.05$. Table II. - Quantitative indices of individual intestinal helminth infections of Rattus norvegicus. 
species - Heterakis spumosa Schneider 1866, Nippostrongylus brasiliensis (Travassos, 1914), Capillaria sp. (Zeder, 1800), Syphacia muris (Yamaguti, 1935) and Trichuris muris (Schrank, 1788) - and two Cestoda species - Hymenolepis diminuta (Rudolphi, 1819) and Rodentolepis fraterna (Stilles, 1906). Data on the prevalence, index of infection, mean infection intensity and mean abundance of gastrointestinal nematodes and cestodes in male and female $R$. norvegicus hosts from urban and suburban-rural habitats separately, are presented in Table II.

The most prevalent were nematodes $H$. spumosa $(36.7 \%)$ but with relatively lower occurrence $(\mathrm{MI}=$ 8.1, MA = 3.0) and $N$. brasiliensis $(16.2 \%)$ with much higher MI (13.8) but lower MA (2.2), and cestodes H. diminuta (30.5\%) with lower MI and MA (6.3 and 1.9 , respectively) and $R$. fraterna (12.6\%) with approximately the same MI as the previous one, but with a much smaller MA (0.7). The species Capillaria sp., T. muris and $S$. muris had a prevalence below $6 \%$, but relatively high MI (10.1, 4.8 and 7.5, respectively) and lower MA (0.6, 0.3 and 0.3 , respectively). No host age or sex-associated differences in the prevalence of infection were found for individual helminth species, except for infections with Capillaria sp. The prevalence of Capillaria sp. was higher in males than in females, mainly due to infected males caught at urban localities. In contrast, the noted tendency $(p=0.06)$ of a higher prevalence of T. muris in urban versus suburban-rural habitats was due to infected females.
According to the infection (invasion) index, the dominant species of helminths in the sample were H. spumosa (1.09), H. diminuta (0.59) and N. brasiliensis (0.36). The influent species were $R$. fraterna (0.09), Capillaria sp. (0.04), T. muris (0.02) and $S$. muris (0.01).

When prevalence of helminthic infection during different seasons was analyzed the following data were obtained: spring (59.8\%), summer (81.1\%), autumn (73.3\%) and winter (66.0\%). Significantly higher prevalence of infection was noted in summer as compared to spring $(\mathrm{p}=0.014)$ or winter $(\mathrm{p}=0.019)$, with a tendency to be higher in autumn as compared to spring. No statistically significant differences were noted between prevalence of infection in rats captured in urban habitats in spring (70.9 \%), summer (81.2\%), autumn (68.7\%) and winter (77.3\%), while significantly higher prevalence of helminthic infection was noted in summer (80.0 \%) as compared to spring (43.2\%; $\mathrm{p}=0.045)$, in autumn (78.6\%) as compared to spring $(\mathrm{p}=0.027)$ as well as in winter $(63.1 \%)$ as compared to spring $(\mathrm{p}=0.042)$ in suburban-rural habitats. The only significant difference in the prevalence of infection between habitat-related was noted during spring $(p=0.009)$. Seasonal changes in the prevalence, index of infection, mean infection intensity and mean abundance of helminths in $R$. norvegicus from urban and suburban habitats are presented in Table III.

When seasonal-related changes in the prevalence of the dominant helminth species was analyzed,

\begin{tabular}{|c|c|c|c|c|c|c|c|c|c|c|c|c|c|c|c|c|c|}
\hline \multirow{2}{*}{\multicolumn{2}{|c|}{ Helminth species }} & \multicolumn{4}{|c|}{ Spring } & \multicolumn{4}{|c|}{ Summer } & \multicolumn{4}{|c|}{ Autumn } & \multicolumn{4}{|c|}{ Winter } \\
\hline & & \multirow{2}{*}{$\begin{array}{l}\mathbf{P} \% \\
30.9\end{array}$} & \multirow{2}{*}{$\begin{array}{c}\mathbf{I} \\
.7811\end{array}$} & \multirow{2}{*}{$\begin{array}{c}\text { MI } \\
8.2\end{array}$} & \multirow{2}{*}{$\begin{array}{c}\text { MA } \\
2.5\end{array}$} & \multirow{2}{*}{$\begin{array}{l}\mathbf{P} \% \\
41.5\end{array}$} & \multirow{2}{*}{$\frac{\mathbf{I}}{1.4570}$} & \multirow{2}{*}{$\begin{array}{l}\text { MI } \\
8.44\end{array}$} & \multirow{2}{*}{$\begin{array}{l}\text { MA } \\
3.5\end{array}$} & \multirow{2}{*}{$\begin{array}{l}\mathbf{P} \% \\
20.0\end{array}$} & \multirow{3}{*}{$\begin{array}{c}\mathbf{I} \\
0.3733 \\
0.6445\end{array}$} & \multirow{2}{*}{$\begin{array}{l}\text { MI } \\
9.3\end{array}$} & \multirow{2}{*}{$\begin{array}{l}\text { MA } \\
1.7\end{array}$} & \multirow{2}{*}{$\begin{array}{l}\mathbf{P} \% \\
36.4\end{array}$} & \multirow{2}{*}{$\begin{array}{c}\mathbf{I} \\
1.1074\end{array}$} & \multirow{2}{*}{$\begin{array}{r}\text { MI } \\
8.4\end{array}$} & \multirow{2}{*}{$\begin{array}{l}\text { MA } \\
3.1\end{array}$} \\
\hline Heter & $\mathrm{U}$ & & & & & & & & & & & & & & & & \\
\hline & $\mathrm{R}$ & 24.3 & 0.4668 & 7.9 & 1.9 & 23.1 & 7.7692 & 7.7 & 7.8 & 27.3 & & 8.7 & 2.4 & 36.9 & 1.0412 & 7.6 & 2.8 \\
\hline$y$ ymen & $\mathrm{U}$ & $\neq$ & & 5. & 2 & 29.2 & & & 1 & 40.0 & & 5.2 & 2 & .9 & 0.9 & 5.6 & 2.3 \\
\hline dimin & $\mathrm{R}$ & 21.6 & 0.3623 & 7.7 & 1.7 & 23.1 & 0.4083 & 7.7 & $1 . \varnothing$ & 36.4 & 1.0579 & 8.0 & 2.9 & 23.8 & 0.4507 & 7.9 & 1.9 \\
\hline Roder & $\mathrm{U}$ & \# & 0. & 5.2 & 0.6 & 23.1 & 0.26 & 5.0 & 1 & 12 & 0 & 5.5 & 0 & 22.7 & 0.2 & 5 & 1.1 \\
\hline fratern & $\mathrm{R}$ & 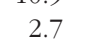 & 0.0051 & 7.0 & 0.2 & 0.0 & 0.0 & 0.0 & 0.0 & 0.0 & 0.0 & 0.0 & 0. & 10.7 & 0.0893 & 7.8 & 0.8 \\
\hline$s$ & $\mathrm{U}$ & & & & & & & & & & & & & 9.1 & & & 1.2 \\
\hline brasi & $\mathrm{R}$ & 8.1 & 0.1030 & 15.7 & 1.3 & 23.1 & 0.8343 & 15.7 & 3.6 & $45.5^{*}$ & 3.1818 & 15.4 & 7.0 & 17.9 & 0.4953 & 15.5 & 2.8 \\
\hline \multirow{2}{*}{ Capillaria sp. } & $\mathrm{U}$ & 9.1 & 0.08 & 10.0 & 0.9 & 13.8 & 0.1981 & 10.3 & 1 & 0. & 0. & 0.0 & & 4.5 & 0.0227 & 11.0 & 0.5 \\
\hline & $\mathrm{R}$ & 0.0 & 0.0 & 0.0 & 0.0 & 0.0 & 0.0 & 0.0 & 0.0 & $18.2 * \circ$ & 0.3140 & 9.5 & 1.7 & 1.2 & 0.0125 & 8.0 & 0.1 \\
\hline \multirow{2}{*}{$\begin{array}{l}\text { Trichuris } \\
\text { muris }\end{array}$} & $\mathrm{U}$ & & & 4 & 0 & , & & 5 & 0 & $20.0^{\circ}$ & & .0 & & 0.0 & & 0.0 & 0.0 \\
\hline & $\mathrm{R}$ & 2.7 & 0.0029 & 4.0 & 0.1 & 7.7 & 0.0296 & 5.0 & 0.4 & 9.1 & 0.0413 & 5.0 & 0.4 & 2.4 & 0.0023 & 4.0 & 0.1 \\
\hline \multirow{2}{*}{$\begin{array}{l}\text { Syphacia } \\
\text { muris }\end{array}$} & U & & & & 0 & & & & & & & & & 9.1 \# & & & 0.8 \\
\hline & $\mathrm{R}$ & 0.0 & 0.0 & 0.0 & 0.0 & 7.7 & 0.0115 & 2.0 & 0.2 & 9.1 & 0.0331 & 4.0 & 0.4 & 0.0 & 0.0 & 0.0 & 0.0 \\
\hline
\end{tabular}

U: urban; R: suburban-rural; significantly different $(\mathrm{p}<0.05)$ from: spring *, summer ${ }^{* *}$, winter ${ }^{\circ}$, suburban-rural ${ }^{*}$.

Table III. - Seasonal quantitative indices of individual intestinal helminth infection of Rattus norvegicus. 
H. spumosa was most prevalent in summer, while $H$. diminuta and $N$. brasiliensis in autumn. The following prevalence of these helminths was noted during different seasons in urban and suburban-rural habitats, respectively: in spring $-H$. diminuta $(41.8 \%$ and $21.6 \%$ ), H. spumosa (30.9 \% and $24.3 \%)-$, in summer - H. diminuta ( $41.5 \%$ and $23.1 \%)$, H. spumosa $(41.5 \%$ and $23.1 \%)$ and $N$. brasiliensis $(0.0 \%$ and $23.1 \%$ ) - in autumn - H. diminuta (40.0\% and $36.4 \%$ ) and $N$. brasiliensis (33.3\% and $45.5 \%)-$, in winter - $H$. diminuta (40.9\% and $23.8 \%$ ) and $H$. spumosa (36.4\% and $36.9 \%)$. The prevalence of $N$. brasiliensis was significantly higher in autumn as compared to spring $(\mathrm{p}=0.0197$ and $\mathrm{p}=0.005)$ in rats from urban and suburban-rural habitats, respectively. The prevalence of Capillaria sp. was higher in autumn as compared to spring $(\mathrm{p}=0.011)$ and in autumn compared to winter $(\mathrm{p}=0.003)$ in rats from suburban-rural habitats. No infection with Capillaria sp. was noted during autumn in rats captured in urban habitats and in rats captured in suburban-rural habitats during spring and summer. Higher prevalence $(\mathrm{p}=0.035)$ of T. muris in autumn compared to winter was noted in rats from urban habitats. This species was not detected in winter. Higher prevalence of S. muris was noted in autumn compared to summer in urban rats. This species was not detected in rats from suburban-rural habitats in spring and summer. $R$. fraterna was not detected in spring in individuals from suburban-rural habitats. Significantly higher prevalence $(\mathrm{p}=0.047$ and 0.049) in urban compared to suburban-rural habitats were noted for $H$. diminuta and $R$. fraterna in the spring and for $S$. muris ( $\mathrm{p}=0.006)$ in the winter. The mean intensity of infection with $H$. spumosa, $R$. fraterna, S. muris and T. muris was higher in autumn than in other seasons, while the higher mean intensity of infection with $N$. brasiliensis and Capillaria sp. was noted in winter.

No more than four parasite species were found in one host. Parasitism involving only one species was found in $51.7 \%$ of the infected rats. Two species of parasites were found in $31.9 \%$ of the infected rats, three species in $14.0 \%$, and four species in $2.4 \%$.

\section{DISCUSSION}

工 $\mathrm{n}$ this study, intestinal helminthic infection of Norway rats from Belgrade area was explored in the context of host sex, age as well as different habitats (urban and suburban-rural) and season. In concordance with the data showing that wild small rodents rarely remain uninfected (Behnke et al., 2001), our study showed a high prevalence of infection with intestinal helminths in wild Norway rats. It might be ascribed to high reproductive potential/high population density, relatively small home range and radius of activity, and omnivorous way of nutrition (Hrgović et al., 1991). In addition, their neighborhood to domestic animals might contribute. Higher prevalence and intensity of intestinal helminthic infection of male compared to female rats and many other small rodents (Ims, 1987; Poulin, 1996; Shalk \& Forbes, 1997; Moore \& Wilson, 2002; Kataranovski et al., 2008) may be attributed to the fact that infected males have larger territories than uninfected males (Brown et al., 1994a) and that the home range of males tend to overlap, which could increase their exposure to infection, while reproductive females show a stronger site-specific organization which could explain low rates of transmission (Davis et al., 1948; Pisano \& Storer, 1948; Calhoun, 1962; Ims, 1987). In addition, the negative impact of the male hormone testosterone on immune defense functions (Grossman, 1989; Folstad \& Karter, 1992) may account for a greater propensity of males for helminth infection. Higher prevalence of infection among male rats may be explained by the hypothesis that, among mammals, the larger bodies of males are easier targets for parasites (Arneberg, 2002). Brown et al. (1994a) proved an overdispersed distribution of Heligmosomoides polygyrus with higher prevalence of infestation in males and heavier individuals of Apodemus sylvaticus. The infected rodents moved more often and faster than uninfected rodents (Brown et al., 1994b). The reasons for these results are still unclear (Klimpel et al., 2007). Age-related differences in the prevalence of infection may reflect the fact that older rats have a longer exposure time to potential infection (Easterbrook et al., 2007). The underlying mechanism(s) of the higher prevalence of Capillaria sp. and T. muris in urban habitats is not known at present, but warrants future attention.

The results of this study showed that $R$. norvegicus from Belgrade area is host to five nematode and two cestode species. This is in line with data which showed that wild Norway rats harbour several helminth species (Webster \& Macdonald, 1995; Battersby et al., 2002; Gomez Villafañe et al., 2008). The results of our study are the first records of intestinal helminth fauna of wild $R$. norvegicus in Serbia, along with recently noted $C$. bepaticum and T. taeniaeformis liver infections in R. norvegicus (Kataranovski et al., 2010).

The monoxenous nature of the life cycle of nematodes may be responsible for this parasitic group dominating the helminth community of wild rats, as parasites with simple and direct life cycles may have more chance to follow the dispersion of their hosts than parasites with indirect life cycles (Bellocq et al., 2003). The longevity of $H$. diminuta in its normal mammalian host 
may contribute to the high prevalence of infection of rats, as once established, it can live as long as its host (Read, 1967). No trematode species was found in the intestines of wild Norway rats, in line with the data from the neighboring country of Croatia (Stojčević et al., 2004). Indeed, these helminths are rare in other geographic areas as well, according to the data from Asia (Seo et al., 1968; Seong et al., 1995; Paramasvaran et al., 2009).

Moderate prevalence of $H$. spumosa (36.7\%) is in accordance with the results of Seo et al. (1968) in South Korea and Stojčević et al. (2004) in Croatia. Research results of Firlotte (1948) in Canada and Tscherner (1996) in Germany, as well as in Argentina (Gomez Villafañe et al., 2008) showed, however, a high prevalence of $H$. spumosa in $R$. norvegicus. Moderate to high prevalence of $H$. diminuta has been reported in different parts of the world including Kuwait (Zakaria \& Zaghloul, 1982), Great Britain (Webster \& Macdonald, 1995), Qatar (Abu Madi et al., 2001; 2005), Croatia (Stojčević et al., 2004), Argentina (Gomez Villafañe et al., 2008) and Kuala Lumpur, Malesia, Southeastern Asia (Paramasvaran et al., 2009). Results on $N$. brasiliensis are in accordance with results from other studies (Stojčević et al., 2004; Gomez Vallafane et al., 2008; Paramasvaran et al., 2009). T. muris was recorded in our country by Habijan-Mikeš (1990) in Apodemus flavicollis, by Kataranovski et al. (2008) in Mus musculus and by BjelićČabrilo et al. (2009) in Clethrionomys glareolus. The low prevalence of this parasite species was attributed by Lewis (1987) to the existence of a strong immune response against this species by hosts, leading to low values of prevalence of the given parasite species in "wild" hosts.

In addition to the significance for parasitological studies in natural ecosystems, our data are of epidemiological importance since some of the detected helminths may occasionally infect humans. In this regard, cases of human infections with Hymenolepis diminuta (Sun, 1988; Lalošević et al., 1996; Tena et al., 1998; Marangi et al., 2003; Mowalvi et al., 2008; Watwe \& Kaur Dardi, 2008) and Capillaria sp. (Lalošević et al., 2008) were reported.

In conclusion, our study contributes to the growing wealth of information on the range and variation in the component community structures of intestinal parasites in wild Norway rats from different regions of the world and from different climatic zones. The important position occupied by these animals in biocenoses, their distribution, population density, the fact that this species cohabitates with humans, and the insignificant knowledge of their gastrointestinal parasites at the territory of Serbia, indicate the necessity of further investigations.

\section{ACKNOWLEDGEMENTS}

This study was supported by grant \# 143038 from the Ministry of Science and Technological Development of the Republic of Serbia. We thank Isidora Deljanin for technical help.

\section{REFERENCES}

Abu-Madi M.A., Lewis J.W., Mickail M., El-Nagger M.E. \& BeHnke J.M. Monospecific helminth and arthropod infections in an urban population of brown rats from Doha, Qatar. Journal of Helminthology, 2001, 75, 313-320.

Abu-Madi M.A., Behnke J.M., Mikhail M., Lewis J.W. \& AlKAABI M.L. Parasite populations in the brown rat Rattus norvegicus from Doha, Qatar between years: the effect of host age, sex and density. Journal of Helminthology, 2005, 79, 105-111.

ARneberg P. Host population density and body mass as determinants of species richness in parasite communities: comparative analysis of directly transmitted nematodes of mammals. Ecography, 2002, 25, 88-94.

Battersby S.A., Parsons R. \& Webster J.P. Urban rat infestations and the risk to public health. Journal of Environmental Health Research, 2002, 1, 4-12.

Behnke J.M., Bajer A., Sinski E. \& Wakelin D. Interactions involving intestinal nematodes of rodents: experimental and field studies. Parasitology, 2001, 122, 39-49.

Belloce J.G. De, Sarà M., Casanova J.C., Feliu C. \& Morand $\mathrm{S}$. A comparison of the structure of helminth communities in the woodmouse, Apodemus sylvaticus, in islands of the western Mediterranean and continental Europe. Parasitology Research, 2003, 90, 64-70.

Bjelić-ČAabrilo O.N., Popović E.J., Šimić S.D. \& Kostć D.S. Nematofauna of bank vole - Clethrionomys glareolus (Schreber, 1780) - from mt. Fruška Gora (Serbia). Archives of Biological Sciences, Belgrade, 2009, 61, 555-561.

BradShaW J. Know your enemy. Environmental Health, 1999, 107, 126-128.

BROOKS J.E. \& Rowe F.P. Vector control series: rodents, training and information guide. World Health Organization, WHO/VBC/87.949, 1987, 107 pp.

Brown E.D., Macdonald D.W., Tew T.E. \& Tood I.A. Apodemus sylvaticus infected with Heligmosomoides polygyrus (Nematoda) in an arable ecosystem: epidemiology and effects of infection on the movements of male mice. Journal of Zoology, 1994a, 234, 623-640.

Brown E.D., Macdonald D.W., Tew T.E. \& Tood I.A. Rhythmicity of egg production by Heligmosomoides polygyrus in wild wood mice, Apodemus sylvaticus. Journal of Helminthology, 1994b, 68, 105-108.

Busch A.O., Lafferty K.D., Lotz J.M. \& Shostak A.W. Parasitology meets ecology on its own terms: Margolis et al., revisited. The Journal of Parasitology, 1997, 83, 575-583.

Calmoun J.B. The Ecology and Sociology of the Brown rat. Public Health Service, Publication No. 1008, US Depart- 
ment of Health, Education and Welfare, Bethesda, Md, 1-288.

Ceruti R., Sonzogni O., Origgi F., Vezoll F., Cammarata S., Giusti A.M. \& SCANZIANI E. Capillaria hepatica infection in Wild Brown Rats (Rattus norvegicus) from the urban area of Milan, Italy. Journal of Veterinary Medicine, 2001, 48, 3, 235-240.

Davis D.E., Emlen J.T. \& Stokes A.W. Studies of homerange in the brown rat. Journal of Mammalogy, 1948, 29, 207225 .

Easterbrook J.D., Kaplan J.B., Vanasco N.B., Reeves W.K., Purcell R.H., Kosoy M.Y., Glass G.E., Watson J. \& Klein S.L. A survey of zoonotic pathogens carried by Norway rat in Baltimore, Maryland, USA. Epidemiology and Infection, 2007, 135, 1192-1199.

Feliu C., Torres J., Gállego J., Gosilbez J. \& Ventura J. Primeros datos acerca de la helmintofauna de los roedores del Delta del Ebro (Península Ibérica). Miscellaneous Zoology, 1985, 9, 55-64.

Feliu C., Renaud F., Catzefelis F., Higot J.P., Durand P. \& Morand S. A comparative analysis of parasite species richness of Iberian rodents. Parasitology, 1997, 115, 453466.

FIRLOTTE W.R. A survey of the parasites of the brown Norway rat. Canadian Journal of Comparative Medicine and Veterinary Science, 1948, 12, 187-191.

Folstad I. \& Karter A.J. Parasites, bright males, and the immunocompetence handicap. American Naturalist, 1992, 139, 603-622.

Genov T. Хелминти на насекомояьните бозайници и гризчите в България. Изделателство на Бъмгарската академия на науките, София, 1984, 1-348 [Helminths of Insectivorous Mammals and Rodents in Bulgaria. Bulgarian Academy of Science, Sofia, 1984, 1-348].

Gomez Villafañe I.E., Robles M.R. \& Busch M. Helminth communities and host-parasite relationship in argentine brown rat (Rattus norvegicus). Helminthologia, 2008, 45, 3, 126-129.

Grossman C. Possible underlying mechanisms of sexual dimorphism in the immune response, fact and hypothesis. Journal of Steroid Biochemistry, 1989, 34, 241-251.

Habijan-Mikeš V. Nematode vrste Apodemus flavicollis Melch. sa Fruške Gore. Master`s Thesis, Faculty of Science, University of Novi Sad, Novi Sad, Serbia, 1990.

Hrgović N., VukićEvić Z. \& Kataranovski D. Basic bioecological characteristics of pest rodents, in: Deratization: Pest rodent control (in Serbian). Jovanovic S. (ed), Decje Novine, Gornji Milanovac, Serbia, 1991, 11-28.

Kataranovski D., Kataranovski M., Savć I.R., Soldatović B. \& MATIĆ R. Morphometric and biochemical parameters as the age indicators in the Norway rat (Rattus norvegicus Berk, 1769). Acta Veterinaria, 1994, 44, 371-378.

Kataranovski D. Distribution of the Norway rat Rattus norvegicus (Berk, 1796) (Rodentia) in the territory of former and present Yugoslavia. Proceedings of an International Symposium: Contribution to the Zoogeography and Ecology of the Eastern Mediterranean Region. Hellenic Zoological Society. Athens, Greece, April 1 to 5, 1999, 99-104.
Kataranovski D.S., VukićEvć-Radić O.D., Kataranovski M.V., RADOvić D. L. \& Mirkov I.I. Helminth fauna of Mus musculus Linnaeus, 1758 from the suburban area of Belgrade, Serbia. Archives of Biological Science, Belgrade, 2008, 60, 609-617.

Kataranovski M., Zolotarevski L., Belij S., Mirkov I., Stošić J., Popov A. \& Kataranovski D. First record of Calodium hepaticum and Taenia taeniaeformis liver infection in wild Norway rats (Rattus norvegicus) in Serbia. Archives of Biological Science, Belgrade, 2010, 62, 431-440.

Key to Helminths of Rodents of the Fauna of the USSR: Cestodes and Trematodes 1978, 1-134. Nauka Moscow.

Key to Helminths of Rodents of the Fauna of the USSR: Nematodes and Acanthocephalans, 1979, 1-185. Nauka Moscow.

KISIELEWSKA K. Ecological organization of intestinal helminth grouping in Cleithrionomys glareolus (Schreb.) (Rodentia). IV. Spatial structure of a helminth grouping within the host population. Acta Parasitologica Polonica, 1970, 18, 177-196.

Lalošević D., Radulović Š. \& Gebauer E. Multipla i recidivirajuća infestacija deteta pacovskom pantljičarom Hymenolepis diminuta [Multiple and recurrent infection in a child with the rat tapeworm, Hymenolepis diminuta]. Vojnosanitetski pregled, 1996, 53, 61-64.

Lalošević D., Lalošević V., Klem I., Stanojev-Jovanović D. \& Pozıo E. Pulmonary capillariasis miming bronchial carcinoma. American Journal of Tropical Medicine and Hygiene, 2008, 78, 14-16.

LEWIS J.W. Helminth parasites of British rodents and insectivores. Mammal Review, 1987, 17, 81-93.

Marangi M., Zechini B., Fileti A., Quaranta G. \& Aceti A. Hymenolepis diminuta infection in a child living in the urban area of Rome, Italy. Journal of Clinical Microbio$\log y, 1987,41,3994-3995$.

Mowalvi G.H., Mobedi I., Mamishi S., Rezaeian M., Haghi Ashtiani M.T. \& Kashi M. Hymenolepis diminuta (Rodolphi, 1819) infection in a child from Iran. Iranian Journal of Public Health, 2008, 37, 120-122.

Paramasvaran S., Sani R A., Hassan L., Kaur H., Krishnasamy M., JefFery J., RAJ S., GHAZALI S.M. \& Hock L.K. Endo-parasite fauna of rodents caught in five wet markets in Kuala Lumpur and its potential zoonotic implications. Tropical Biomedicine, 2009, 26, 67-72.

PisAno R.G. \& STORER T.I. Burrows and feeding of the Norway rat. Journal of Mammalogy, 1948, 29, 374-383.

READ C.P. Longevity of the tapeworm, Hymenolepis diminuta. Journal of Parasitology, 1967, 53, 1055-1056

Redrobe S.P. \& Petterson-Kane J.C. Calodium hepaticum (syn. Capillaria hepatica) in captive rodents in a zoological garden. Journal of Comparative Pathology, 2005, 133, 73-76.

Seo B.S., Rim H.J., Koo B.Y., Hong N.T. \& Yoon J.S. Studies of the parasitic helminths of Korea. III. Nematodes and Cestodes of rodents. The Korean Journal of Parasitology, 1968, 6, 123-131.

SeOng J.K., Hih S., LeE J.S. \& OH Y.S. Helminths in Rattus norvegicus captured in Chunchon, Korea. The Korean 
Journal of Parasitology, 1995, 33, 235-237.

Stojčević D., Mihaljević Z. \& Marinčulić A. Parasitological survey of rats in rural regions of Croatia. Veterinary Medicine-Czech., 2004, 49, 70-74.

Sun T. Parasitic disorders: pathology, diagnosis and management. Library of Congress Cataloging-in-Publication Data, New York, 1988, 402-403.

Tena D., Pérez Simón M., Gimeno C., Pérez Pomata M. T., Illescas S., Amondarain I., Gonzaléz A., Dominguez J. \& BISQUERT J. Human infection with Hymenolepis diminuta: case report from Spain. Journal of Clinical Microbiology, 1998, 36, 2375-2376.

TsCHERNER W. Nematoden Der Familie Heterakidae Im Tierpark Berlinfriedrichsfelde. European Association of Zooand Wildlife Veterinarians (EAZWV) First scientific meeting, May 16-18, 1996, Rostock, Germany [Nematodes of the Heterakis Family In The Zoo Berlin-Friedrichsfelde].

Watwe S. \& KaUR Dardi C. Hymenolepis diminuta in a child from rural area. The Indian Journal of Pathology and Microbiology, 2008, 51, 149-151.

Webster J.P. \& Macdonald D.W. Parasites of wild brown rats (Rattus norvegicus) on UK farms. Parasitology, 1995, 111, 247-255.

WeBSTER J.P. Wild brown rats (Rattus norvegicus) as zoonotic risk on farms in England and Wales. Communicable Disease Report Review, 1996, 6, 46-49.

ZaKaria M. \& Zaghoul T.M. Parasitic infection of Rattus norvegicus in Kuwait. Proceedings of the First Symposium on Recent Advances in Rodent Control, Kuwait, 1982, 136-143.

Received on May $6^{\text {th }}, 2010$ Accepted on October $8^{\text {th }}, 2010$ 